\title{
Developing World: Increasing Jordanian Tourism: A Strategic Plan
}

\author{
Dr. Khaled K. Alafi \\ Department of Management, Faculty of Finance and Business Administration \\ The World Islamic Sciences \& Education University \\ P.O.Box 1101, Postal Code 11947, Amman, Jordan \\ E-mail: allafykhaled99@yahoo.com
}

Received: Nov. 1, 2013 Accepted: December 25, 2013 Published: January 1, 2014

doi:10.5296/jmr.v6i1.4715 ～URL: http://dx.doi.org/10.5296/jmr.v6i1.4715

\begin{abstract}
This paper focuses on ways to improve tourism facilities and revenues in a cosmopolitan nation with few resources but enriched by ancient historical sites and a fascinating culture. It is significant as a pattern for other developing Middle Eastern Nations, even those presently oil-rich, because tourism depends on a sustainable continuing resource. The introduction places Jordan in its world political situation, and summarises its ancient and unique tourism attractions, including medical, and educational. Background geographical and population characteristics are outlined with $30 \%$ unemployed youth. Tourism employs $22 \%$ of the population overall and brings in 5.5\% of GDP. As a case study, a strategic plan is developed from a SWOT analysis considering the latest literature to guide internal sustainable development and encourage tourism, lure outside investment, increase its entrepreneurial middle class, improve revenue and suggest job opportunities for youth. Problems are collated from the SWOT Weaknesses and Threats to expose areas for further study and development within the governorates, utilising Jordan's excellent educational resources for analysis to derive further national improvements and lead Middle Eastern tourism.
\end{abstract}

Keywords: International tourism, Jordan, marketing, Strategic plan, Tour packages 


\section{Introduction}

Tourist income is vital for many areas of the historic Middle East, with the advantages of a long background of early settlement and cultural development, a basis of European culture. Politically unstable Egypt, and the original "fertile crescent" countries of Syria, Iran, Iraq and Lebanon fall into this interesting developing world group. Jordan has been occupied continuously through centuries of nomads, prophets, Silk Road merchants, Romans, their Byzantine successors, Arabs, Christian crusaders, and Ottoman Turks. In the present 2013 political situation where this tourism market is threatened by today's surrounding unrest of “Arab spring”, Jordan stands out strategically in the core of the region as a safe, secure destination with a stable, almost democratised Hashemite Kingdom ruled by King Abdallah II since 1999; a mark of progressiveness is $20 \%$ seats reserved for women in municipal elections. Abdallah suggested concentrating on socio-economic reform, to improve education and healthcare and to develop housing for both the armed forces and civilians (Jewish Virtual Library, 2008). This nation also offers tourists an exceptionally low crime rate.

Economically Jordan would like to increase tourism investment, because of its political stability, religious toleration, a higher quality of life, better healthcare and education compared with surrounding areas, cosmopolitanism, exquisite cuisine, friendly and welcoming people, together with a reasonably liberal social and economic environment (CIA 2012), it is called by the World Bank "an upper middle income country" (data.Worldbank.org.). Since 2011, due to the global financial crisis and the Arab Spring unrest, tourist arrivals have declined sharply (CIA World Factbook 2012), amounting to 5.9\% of GDP in 2012 but projected to be only 5.4\% in 2023 (WTTC Economic Impact, 2013:11). International tourism worldwide generated \$US1.3 trillion in earnings for export with a predicted growth of $3 \%-4 \%$ in 2013. The latest available statistics show incoming tourists came from Europe (48\%), Asia and Pacific (24\%), Americas (19\%), Middle East (5\%) and Africa (3\%). The majority go to first world nations, which also gets most revenue because they offer better tourism facilities and development (UNWTO 2013). This means further improvement in sustainable tourism development is urgently required, the subject of this paper.

\section{Jordan today}

\subsection{Overview and present tourist attractions}

In an area of nearly 90 000sq. km., Jordan has a population of 6.51 million, a life expectancy of 80.8 years, a GDP of US\$36.9B with an inflation rate of $4.4 \%$ (CIA Factbook: Find the Data, 2012). Despite modest political and economic reforms, Jordanians are now requesting even more political liberalisation, with greater economic reforms and improvements. This constitutional monarchy has a mainly appointed government. Twelve governorates centred on the major cities provide local government. The Chamber of Deputies is elected (2013) by universal suffrage (over 18) while the judiciary is independent. World Bank international tourism receipts for 2011 in Jordan were US\$3 589 million, a drop from US\$4 390 million in 2010 (WTO Yearbook 2013). 
1.1.1 Tourism targets

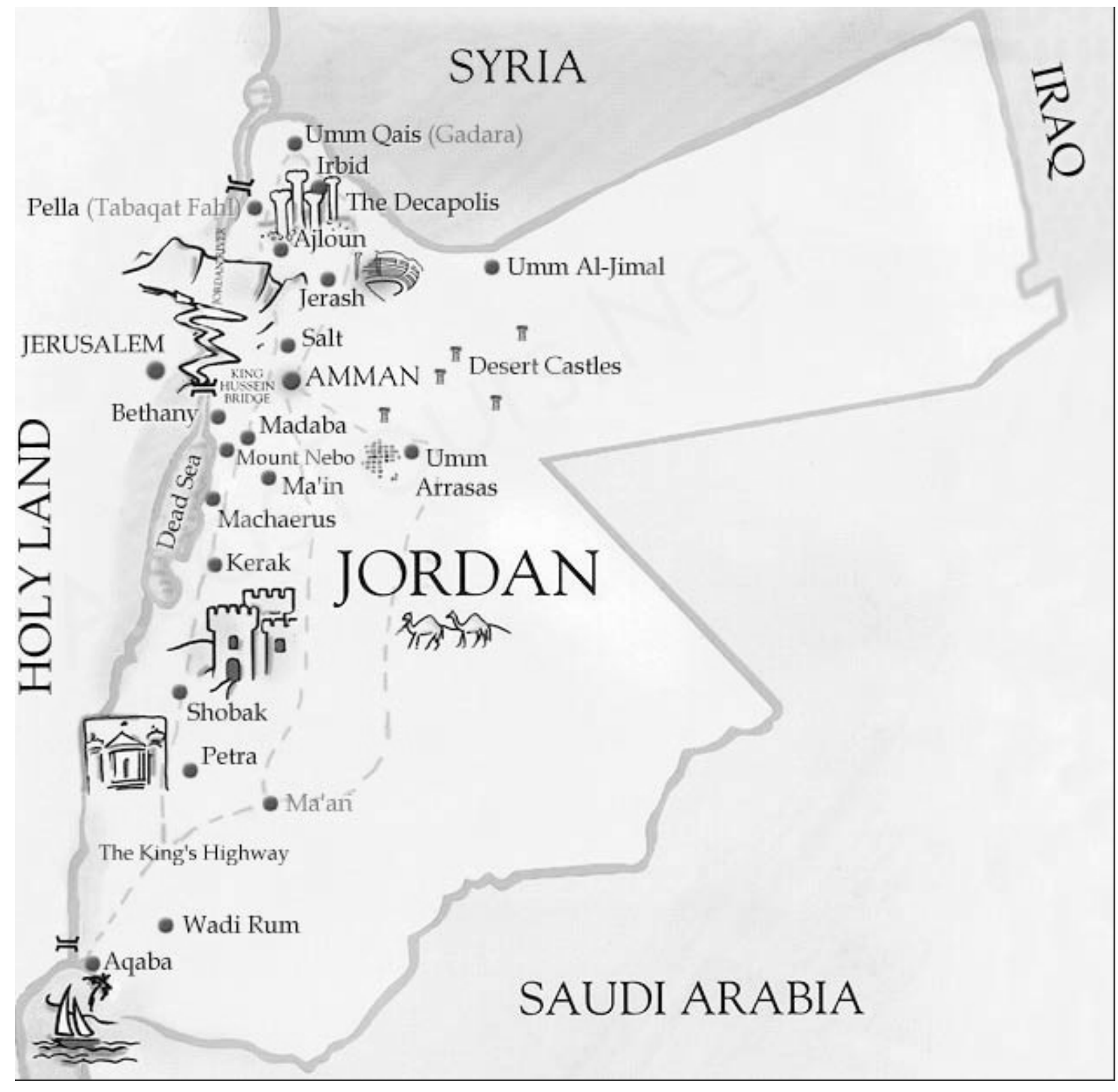

Source: Jordan Map \& Sites: At-last Tours: Jordan's tourist attractions map.

Figure 1. Tourist Attractions and Cities of Jordan

Figure 1 above shows major cities with the capital of Amman housing c. 2.3 M. people. This city was inhabited in the Neolithic and Iron ages. Hellenistic, Roman (two theatres) and Arab Islamic remains still exist; all can be explored in detail in the three museums. For the tourist this mix of ancient and ultra-modern is intriguing with 5 star hotels and modern buildings, clubs, entertainment, other hotels, amazing sweets, with traditional coffee houses for shisha downtown and in the old city, where artisans produce and sell traditional wares (Jordan Tourism Board 2013). 
Alrabwa (2013) of the private sector Islamic Chamber of Commerce and Industry (ICCI) explains that Jordan applied tourism industry long-term planning in fields of leisure, religious, cultural, ecological and medical areas with attention to factors of tourist products, management, human resources, marketing and financing. An undated ICCI presentation previously identified seven constraints to development including insufficient capital, inability to access money, insufficient policy or regulation, out-of-date technology, limited productivity, low quality control, insufficient marketing and marketing skills, limited networking (ICCI, possibly 2007:5). Suggested initiatives are workshops to build capacity, exchanges to coordinate Small and Medium-sized Business Enterprise (SME) experts among members, support and mechanisms for supporting technology upgrade, private-sector-led SME groups to develop networks (ICCI, 2007:7).

Jordan's greatest development has been in urban heritage as a major tourism source because tourists are fascinated by the manifestation of culture over time in varied civilisations as found in the following places (in bold) starring in package products.

Jordan Holidays and Adventure Tours (2013) say the most important site historically for leisure travellers is rediscovered Petra, the ancient Nabataean city, then Roman Jerash, both world class historical and cultural sites. For Christians mainly from Europe and USA, there is the stream where Jesus was baptised, Mt. Nebo, reputed site of Moses' tomb, a site of John the Baptist's preaching, a castle noted for his beheading, and many desert castles from Crusader times (shown by Figure 1 symbols), while robed nomadic Bedouins still shepherd their flocks in this same desert, while oryx and gazelle graze in the eastern mountains parks like Ajlun (N. of Amman); Azraq wetland bird sanctuary (Jordanian Eastern Desert); Dana Biosphere reserve (300 sq km); Mujib Reserve (in the rift valley gorge with rare cats, goats and ibex); Shamwari Reserve (breeding endangered Middle East oryx, ostriches, gazelles and onagers) (Jordan Tourism Board, 2013). Map 1 also locates castles, such as the initially biblical Moabite town of Karak built in 1132 by the Crusader King Fuk of Jerusalem, reconquered by Saladin in 1188 . This is a walled city with a four- storey defensive castle of great thickness.

Some major urban tourist attractions in the Figure 1 map above, are described below moving north to south. NW. of Amman, the Roman ruins of Jerash, is a modern city still occupied through 6500 years, though the ancient part was uncovered 70 years ago. The ancient, beautifully preserved Roman paved and walled provincial capital has stone gates, colonnades, theatres, squares, temples, baths and fountains.

Madaba SW has religious Byzantine and Umayyad mosaics, the most famous one has 2 million pieces depicting a $6^{\text {th }}$ century map of the Holy Land's hills and valleys, in the Coptic Church of St. George: from Egypt to Palestine to Jordan. E. the Dead Sea coast is $400+\mathrm{m}$. below sea level with amazing salt crystal patterns on the shores, mineral medically-advantageous mud baths or facials available and mineral-rich buoyant water for floating, and international resorts for pampering.

Further south, the end of the winding and narrow Siq gorge terminates in the magnificently carved treasury of Petra, an 1800 year old trading "Rose Red City” carved into solid pink or 
multi-colored sandstone, with tombs, a theatre, multiple streets and water conduits plus a church. Referred to in the Old Testament, but built in 312 BCE on as capital of Nabataeans, in Hellenistic-Roman style, this world-heritage site was discovered in 1812. East is Wadi Rum, a magnificent red desert landscape of yellow and orange mountains, with raptors, ibex and wolves, 2000 species of wild flowers and plants in spring, where desert journeys on camels or 4WDs and dune camping are available and Bedouin traditional meals catered.

Farthest south is Aquaba for seaside recreation, 27km of Aquaba Gulf on the Red Sea has the furthest north coral reef ecosystem, 1000 species of fish, crustaceans, corals (330 species) and mammals to view while diving. Top hotels and resorts are situated here in a Special Economic Zone to improve tourism and its economy (Eco \& Nature, Jordan Holidays \& Adventure Tours, www.onthegotours.com. Jordan ,2013).

Medical tourism

In 2010, 8 million tourists visited, bringing in $\$ 3.4$ billion in revenues, according to the Jordanian Ministry of Tourism, from Arab and other nations,. This amount rises to $\$ 4.4$ billion with medical tourists included, Saudi Arabians and Americans in the majority (Islamic Chamber of Commerce \& Industry 2012). In 2010 a study by Jordan's Private Hospitals Association found $1 / 4$ million patients covering 102 nations were treated. World Bank says Jordan is the region's top medical destination and overall fifth in the globe (Jordanembassyus.org, 2011). The marketing focus is the old Soviet Union states, Europe and USA (with 10-30\% less cost than US for organ transplants) cosmetic surgery, infertility, open-heart surgery, neurological surgery, cancer treatment, bone operations and laser vision corrections (AMEinfo.com, 2010; Medical Tourism Corp. 2013).

\subsection{Geography and population}

Geographically, Jordan is an arid interior desert. Some winter rain occurs in the west but the east is desert plateau with lightly grassed steppe rising west to highlands (highest mountain 1 $854 \mathrm{~m}$ ) separated by the great Rift Valley continuing south to the Gulf of Aqaba. The country's only natural resources are phosphates, shale oil and potash with less than $2 \%$ arable, $1 \%$ under permanent crops, with under $200 \mathrm{sq}$. km irrigated. There is less than $1 \% \mathrm{cu} k m$ of renewable water resources therefore supplementary water for cities is needed and fresh food imported. Environmental issues mean that desertification follows from limited natural water supplies, with deforestation and overgrazing causing soil erosion. American Sharp (2012) admits that slow growth domestically, subsidies for energy and food, and huge public sector employment (30-50\%) gives the Jordanian nation habitually a large annual budget deficit which international aid partly offsets (Sharp, 2012: 7-8).

The population is 98\% Arab, mainly Sunni Muslim speaking Arabic, though English is widely understood and the society is largely liberal and secular (RT News 2012) The population is $104^{\text {th }}$ in the world, young with one third under 14 , one fifth is $15-24$, and over one third in the 25-54 age; with average 22.5 years. Population growth is low, $182^{\text {nd }}$ in the world. About $83 \%$ of the population live in cities mainly Amman. The Health system is one of the best in the region (8\% of GDP: 2010) or $59^{\text {th }}$ in the world, with about 2.5 physicians 
per 1000 people and 1.8 hospital beds per 1000 in the many hospitals. In education, 96\% of population are literate and schooling is 13 years. There are multiple universities which explains why Jordan ranks third in Middle East innovation. However, youth unemployment $15-24$ ages is about $30 \%$ or $26^{\text {th }}$ in the world (CIA World Factbook - Middle East: Jordan, 2013). In general, Jordan is classified as a nation of "medium Human development" (U N Human Development Report 2011.

Refugees, Immigrants

UNRWA claims $1.95 \mathrm{M}$ Palestinian refugees were in Jordan in 2008. About $60 \%$ of the Jordanian population are immigrants with unconfirmed Iraqi refugee numbers between $3 / 4$ and one million, mostly in Amman (Leyne, BBC News, 2007) and 535405 Syrian refugees have joined those since 2012 possibly now 1.5 million total, mainly in the northern UN camps, of which Za'atri is the world's second largest camp (UNHCR, 2013); and in Jan. 2013 this had cost Jordan JOD 590 M or 3\% of GNP up to the previous November 2012 (Jordan Times, 29 Jan, 2013).

\section{Literature review}

\subsection{Factors involved}

Early Gee (1997) discusses the importance of factors of broader distribution of international companies (hotel chains, airlines, transportation businesses) world finance and wars (particularly in the Middle east) shaping tourism externally; internally demographics, social and political changes, developments both economic and in finance, trade, technological growth and developing hotel and transport infrastructure, products offered and marketing methods (particularly online) create changes in options and subsequent market offerings (Gee 1997). ILO (2010) agreed that drivers of growth in tourism, hospitality and travel were better civil aviation services, information and communication technology utilising internet booking sales, plus widespread marketing of tourist packages and trips. However, tourists often pursue exploration of different communities based on race, religious or political ideology and other unique cultural features. Hadan (2008?) in a presentation to the Islamic Chamber of Commerce and Industry world to enhance the regional private sector role records seven issues constraining business: insufficient policy and regulations, no enough capital or capital access, out-of-date technology, lack of productivity, quality control lacking, insufficient marketing and management skills, inadequate networking (ICCI p.6). His solutions are providing workshops to expand capacity, with exchange of SME experts among nations, support to upgrade technology, networking of private-sector SME associations and Chambers of Commerce and Industry (ICCI 2008 p. 7). Only some of these regional issues apply to Jordan.

Mustafa (2010) specifically discussed globalisation and tourism for Jordan, in terms of unconstrained world distances or borders and their effects on the Middle East, stressing the value and use of increased communication and transportation in enabling more global interaction which erodes cultural differences. He concludes that Arab nations saw largely 
economic benefits from tourism, paying less attention to socio-cultural and environmental effects. He recommends more sustainable development and planning (Mustafa, 2010).

An issues paper for the Global Dialogue Forum for the Hotels, Catering, Tourism (HTC) Sector (23-24 November 2010) suggests “education, vocational training, training upgrades and HRD are key requisites for the operational effectiveness of the sector” (ILO, 2010:60). Their reasoning lies in the restricted qualifications in the profession, particularly female employees at the base of the industry where skills development and training are a priority, not only occupational skills but soft skills [Emotional Intelligence Quotient] or interpersonal friendliness skills (Panjaanen, 1992). It is also suggested that ongoing consultation between workers' representatives and managers/owners on employee attitudes and satisfaction as well as possible outsourcing of information and communication technologies. In short, workplace practices, industrial relations, development of human resources, qualification establishment and social responsibility. The paper explains "the tourism industry and its internationally operating enterprises are considered as actors of social development and poverty reduction in the destinations" (HTC Issues ILO, 2010 p.60) Tourism sustainability is an unfinished problem involving environmental impact, efficiency and consumption levels, innovation and creating competitive advantage as a stakeholder collective responsibility specifically depending on employees' input to employers for the benefit of customers (ILO 2010: 61). Government as the integrating force provides infrastructure services like water, power, restaurants, transportation hotels and effective marketing, sanitation, coordinating public-private sectors, security; all of which create and ensure local jobs.

Training quality in both public and private sectors, effective social dialogue with a clearly explained and understood appraisal system can improve employee development in private, international companies and government service. In SMEs vocational training and education should improve productivity, particularly with emphasis on managing technology and information. With an ageing tourist population, different soft skills are required even more. "To be effective, sectoral approaches to skills development might want to include long-term national growth strategies and governments might want to collaborate with social partners and other labour market stakeholders to identify gaps and shortages of skills” (ILO 2010). Governments are advised to ensure that "school-to-work transition is facilitated for young workers, that enterprises offer sufficient training places and apprenticeships, or that quality skills and employment merges labour market measures with lifelong learning” (Global Unions, 2010:7).

To increase the tourism's contribution to national wealth and help to develop regions in order to bring in wealth and provide job opportunities, countries like Jordan with its extensive, varied cultural history, natural and scenic resources detailed in Section 1.1.1 above, are in a good position to seek foreign investment to exploit or better manage their assets (IVC 2006).

World Travel and Tourism Council (WTTC)(2013) reports annually at a global summit and provides relative facts, figures and graphs annually on 184 countries, so this paper will look at some of this London research to rank the Jordanian Tourism industry. 
2.2 Value of Tourism and travel to Jordan: 2012, 2013 and forecast 2013-2023

Figure 2 below depicts the main points: (bold terms defined following)

Total contribution generated by tourism to GDP includes what is directly generated (hotels, airlines, travel agents, passenger transport services, directly utilised leisure industries, operators and restaurants). Employment total contribution consists of the number of jobs directly created within the Travel and Tourism ( $\mathrm{T} \& \mathrm{~T}$ ) industry including indirect and induced contributions. These last include three things: money spent by all groups directly in $\mathrm{T} \& \mathrm{~T}$ industry including new capital expenditure/investment for tourist use; collective government spending supporting the tourist industry at all levels, promotion, information services, administrative and public services; supply-chain effects covering direct purchase of internal services and goods by separate sectors of $\mathrm{T} \& \mathrm{~T}$ used as inputs for final tourism output. Induced contribution broadens to include contribution to GDP use of spending by the direct and indirect employees affected by T \& T.

A third element compared is visitor exports. This is internal spending by internationals for leisure or business trips, inclusive of transport. Capital investment combines money spent by sectors involved in T\&T industry including new buildings for accommodation, restaurants, equipment for leisure and passenger transportation specifically for tourists (WTTC p.15).

Summary tables reproduced from WTTC (2013) giving 2012-3 figures are discussed below as a basis for further development of this vital industry.

\begin{tabular}{|c|c|c|c|c|c|c|}
\hline Jordan & $\begin{array}{c}2012 \\
\text { JODmn }^{1}\end{array}$ & $\begin{array}{c}2012 \\
\% \text { of total }\end{array}$ & $\begin{array}{c}2013 \\
\text { Growth }\end{array}$ & JODmn ${ }^{1}$ & $\begin{array}{c}2023 \\
\% \text { of total }\end{array}$ & Growth ${ }^{3}$ \\
\hline Direct contribution to GDP & $1,277.1$ & 5.9 & 2.3 & $1,918.2$ & 5.4 & 3.9 \\
\hline Total contribution to GDP & $4,750.5$ & 22.0 & 2.3 & $7,406.5$ & 20.9 & 4.3 \\
\hline Direct contribution to employment & 87 & 5.1 & 1.5 & 105 & 4.7 & 1.8 \\
\hline Total contribution to employment $t^{4}$ & 333 & 19.4 & 1.5 & 417 & 18.7 & 2.1 \\
\hline Visitor exports & $3,119.0$ & 31.9 & 2.2 & $4,594.6$ & 30.4 & 3.7 \\
\hline Domestic spending & 393.3 & 1.8 & 3.3 & 650.1 & 1.8 & 4.8 \\
\hline Leisure spending & $3,129.3$ & 5.2 & 1.9 & $4,550.8$ & 4.6 & 3.6 \\
\hline Business spending & 382.9 & 0.6 & 5.7 & 693.9 & 0.7 & 5.5 \\
\hline Capital investment & 400.9 & 7.5 & 0.7 & 627.6 & 7.6 & 4.5 \\
\hline
\end{tabular}

Source: Summary tables estimates, forecasts (WTTC Economic Impact 2013, London, p.11)

Figure 2. Jordan's Tourism GDP and employment contribution, visitor numbers \& spending, with capital investment. 2012, 2013 and projected to 2023

Some selected points, noting world rankings are absolute contributions from184 nations: 
- $\quad$ total T \& T contribution to GDP $\left(68^{\text {th }}\right.$ in world) in 2012 is $22 \%$ or supporting over one fifth of the population; but predicted to drop by $1 \%$ of this total by 2023 , while overall 10 yr. growth is $4.3 \%$.

- 333000 jobs ( $73^{\text {rd }}$ in world) in 2012; predicted increase to 417000 in 2023 dropping $0.7 \%$ of total but growing overall $2.1 \%$ in the 10 years to 2023

- visitor exports (53 ${ }^{\text {rd }}$ in world) and leisure spending is very good at around $30 \%$

- capital investment ( $79^{\text {th }}$ in world) is $7.5 \%$ of total spending (JOD400.0 million) also growing nicely over the 10 year period to a projected 7.6\% of total or JOD627.6 million by 2023 at present rates.

Considering the small size and population of the nation (104 $4^{\text {th }}$ in world), its results are well into the top half of the 184 countries between $53^{\text {rd }}$ (visitor exports) and $79^{\text {th }}$ (capital investment); so government policy is obviously exploiting its tourism resources well. To produce a further improved result, the proposed aim is to design a strategic plan to help further develop outside investment in tourism, to increase its domestic entrepreneurial middle class, to provide employment for young people and to improve the GNP revenues from this important but promising industry.

\section{Methodology}

A case study seemed the best means of examining a small, peaceful Middle East nation dependent on tourism to bring in overseas funds, particularly since it provides such a rich source of varied needs by tourists. As a pattern for other small nations in similar economic conditions, the plan could leading them to grow and diversify their own industries.

\section{SWOT analysis and Strategic plan}

\subsection{SWOT Tourism analysis}

In generating a strategic plan, a SWOT matrix analysis (Strengths, Weaknesses of internal attributes for Jordan, External Opportunities and Strengths) of relevant factors should be constructed to consider decision-making inputs. Analysing this list germinates creative new strategies to use internal strengths, preventing internal weaknesses; and then consider external (environmental) opportunities leads to new ways of exploitation and defense against threats identified in the strategic plan (MindTools, 2006). Two tables below, A and B, derived from the SWOT matrix (Winer, 2006) give the starting data for meaningful assessment.to achieve a strategic plan vision and objectives.

\begin{tabular}{|l|l|l|}
\hline JORDAN & $\begin{array}{l}\text { STRENGTHS -helpful to achieve } \\
\text { objectives }\end{array}$ & $\begin{array}{l}\text { WEAKNESSES }- \text { harmful in } \\
\text { achieving objectives }\end{array}$ \\
\hline $\begin{array}{l}\text { Internal } \\
\text { attributes }\end{array}$ & $\begin{array}{l}\text { Central geographical location: cross } \\
\text { roads for leisure \& business in } \\
\text { Europe, Asia/Pacific and Africa }\end{array}$ & $\begin{array}{l}\text { Area surrounded by wars \& political } \\
\text { unrest in the } 21^{\text {st }} \text { century }\end{array}$ \\
\hline
\end{tabular}




\begin{tabular}{|c|c|}
\hline $\begin{array}{l}\text { Close to international travel transport } \\
\text { hub of UAE: Dubai \& Abu Dhabi, } \\
\text { with untouched eco- environments, } \\
\text { distinct indigenous cultures and } \\
\text { cuisine, leisure, religious, ancient } \\
\text { cultural, educational and medical } \\
\text { attractions }\end{array}$ & $\begin{array}{l}\text { Regarded as third World Nation: } \\
\text { desert with limited natural resources, } \\
\text { water, agriculture; food and energy is } \\
\text { subsidised, public sector is very large } \\
\text { \& annual deficit in budget is offset in } \\
\text { part by overseas aid (Sharpe, 2012). }\end{array}$ \\
\hline $\begin{array}{l}\text { Political stability, economic security } \\
\text { \& financial steadiness assisted by } \\
\text { location in a wealthy oil-rich area }\end{array}$ & $\begin{array}{l}\text { Focus of millions of refugees from } \\
\text { surrounding countries since } 1947 \\
\text { costing 3\% of GDP to Nov., } 2012 \\
\text { (Jordan Times, 29 Jan,2013) }\end{array}$ \\
\hline $\begin{array}{l}\text { High education level of population } \\
\text { available for tourism further training } \\
\text { \& centre of Arab educational tourism } \\
\text { especially since Sept. 11, } 2001 \\
\text { (ESCWA 2007) }\end{array}$ & $\begin{array}{l}\text { High youth unemployment (30\%) in } \\
\text { 15-24 age group (CIA World } \\
\text { Factbook, 2013) }\end{array}$ \\
\hline $\begin{array}{l}\text { Central Bank with proper transparent } \\
\text { banking procedures for secure } \\
\text { investment from overseas (IVC, } \\
\text { 2006; WTTC, 2013) }\end{array}$ & $\begin{array}{l}\text { Need for further investment in nation } \\
\text { and specifically, valuable tourism } \\
\text { resources (ILO 2010; !CCI 2010; } \\
\text { WTTC 2013) }\end{array}$ \\
\hline $\begin{array}{l}\text { Access to world markets via free } \\
\text { trade agreements; access to markets } \\
\text { in Iran, Iraq and Saudi Arabia }\end{array}$ & $\begin{array}{l}\text { Insufficient promotion of opportunities } \\
\text { to utilise these trade agreements as eg. } \\
\text { entrepot centre for Middle East trade }\end{array}$ \\
\hline $\begin{array}{l}\text { Close to main tourism markets of } \\
\text { NW Europe, bringing main source of } \\
\text { foreign exchange for } \\
\text { balance-of-trade \& foreign exchange } \\
\text { earnings (Mustafa, 2010:41) }\end{array}$ & $\begin{array}{l}\text { Socio-culturally, little appreciation by } \\
\text { certain sectors of benefits of tourism, } \\
\text { with poor reactions and attitudes } \\
\text { (Mustafa, 2010:p43) }\end{array}$ \\
\hline $\begin{array}{l}\text { Offers high quality medical tourism } \\
\text { services, Health was 8\% of GDP in } \\
2010 \text { (Medical Tourism Corp. 2013, } \\
\text { CIA) }\end{array}$ & $\begin{array}{l}\text { Lack of popular advertisement for } \\
\text { medical/leisure trips in USA and } \\
\text { Europe; any advertisement in E. Asia? }\end{array}$ \\
\hline $\begin{array}{l}\text { Extensive good road and excellent } \\
\text { hotel infrastructure (capital, large } \\
\text { cities \& coastal beach resort of } \\
\text { Aqaba), international standard } \\
\text { airports; } 2007 \text { Intercontinental Hotels } \\
\text { announced } 20 \text { Holiday Inns by } 2011 . \\
\text { Easy Group will also bring } 38 \text { hotels } \\
\text { to region (APN, 2007) }\end{array}$ & $\begin{array}{l}\text { Need for encouraging investment for } \\
\text { more small airports, heliports to } \\
\text { encourage fly/drive tourist day } \\
\text { packages to relatively remote locations } \\
\text { such as Petra, Jerash, Wadi Rum and } \\
\text { desert oases from Amman; develop } \\
\text { "homestay” visits to Bedouin sites and } \\
\text { local culture homes (ILO 2010) }\end{array}$ \\
\hline $\begin{array}{l}\text { Rich historical, archeological, } \\
\text { cultural \& religious sites: location of } \\
\text { earliest civilisations of the Fertile }\end{array}$ & $\begin{array}{l}\text { Stakeholders require tourism } \\
\text { education and training; insufficient } \\
\text { local guides available for these areas; }\end{array}$ \\
\hline
\end{tabular}




\begin{tabular}{|l|l|l|}
\hline $\begin{array}{l}\text { crescent, origin of 3 major world } \\
\text { religions (Judaism, Christianity and } \\
\text { Islam) (Jordan Tourism Board, 2013) }\end{array}$ & $\begin{array}{l}\text { so need for tourism guiding/ training } \\
\text { courses for unemployed youth to boost } \\
\text { slow employment growth predicted } \\
\text { thus increase available trained human } \\
\text { resources (WTTC, 2013) }\end{array}$ \\
\hline $\begin{array}{l}\text { High national investment (7.5\% of } \\
\text { GDP) in tourism facilities \& }\end{array}$ & $\begin{array}{l}\text { Strategies to utilise/encourage } \\
\text { infrastructure (WTTC, 2013) } \\
\text { small businesses \& medium } \\
\text { enterprises (SMEs) not yet obvious } \\
\text { (Pearce 2002) }\end{array}$ \\
\hline
\end{tabular}

Figure 3A. JORDAN: Internal Strengths and Weaknesses

\begin{tabular}{|l|l|}
\hline Opportunities to be exploited & Threats for determining defence \\
\hline $\begin{array}{l}\text { Focus of intra-regional Arab tourism - similar } \\
\text { customs, language \& traditions; and Arabs visitors } \\
\text { use furnished apartments \& family housing for their } \\
\text { large family holidays or visits thus limited } \\
\text { infrastructure outlay (ESCWA 2007) }\end{array}$ & $\begin{array}{l}\text { Lack of intraregional regular flights, } \\
\text { limited provision of tourist products } \\
\text { and inability to supply adequate } \\
\text { services (Mustafa, 2010:42) }\end{array}$ \\
\hline $\begin{array}{l}\text { Egyptian and Eastern Mediterranean package tours } \\
\text { include Jordan as part of tours: expand these to all } \\
\text { Jordan (only) tours: particularly well-promoted } \\
\text { leisure breaks in long flights stopping at at UAE: } \\
\text { 3-10 day stopover fly/ drive cultural tours of Jordan: } \\
\begin{array}{l}\text { Amman base to Jerash, Mt. Nebo, Kerak, Dead Sea, } \\
\text { Petra, Aqaba, Wadi Rum, Amman }\end{array}\end{array}$ & $\begin{array}{l}\text { Lack of growing East Asian (Chinese, } \\
\text { Japanese, Singaporean) tourist } \\
\text { numbers (WTTC 2013) }\end{array}$ \\
\hline $\begin{array}{l}\text { Utilise foreign managements and investment with } \\
\text { Eardern region }\end{array}$ \\
$\begin{array}{l}\text { Jordanian nationals training as 2IC, as part of } \\
\text { investment agreements to learn tourism/hotel asset } \\
\text { management }\end{array}$ & $\begin{array}{l}\text { Specific hotel management and } \\
\text { tourism management courses not } \\
\text { available at nearby universities where } \\
\text { fieldwork could be performed }\end{array}$ \\
\hline $\begin{array}{l}\text { Raise 79th/184 in the world in tourist investment into } \\
\text { a higher international number given the cultural } \\
\text { capital \& advantages }\end{array}$ & $\begin{array}{l}\text { Few advertisements for growing } \\
\text { wealthy East Asian (Chinese, Indian, } \\
\text { Japanese, Singaporean) tourist } \\
\text { numbers (WTTC 2013) }\end{array}$ \\
\hline $\begin{array}{l}\text { Increase medical and educational tourism between } \\
\text { Arab countries by advertising (as happening since } \\
\text { 2001) (ESCWA 2007) }\end{array}$ & $\begin{array}{l}\text { Few regular international or } \\
\text { inter-regional air flights between } \\
\text { countries (Mustafa, 2010:p42) }\end{array}$ \\
\hline $\begin{array}{l}\text { Similar customs, religion, language with } \\
\text { neighbouring nations make air travel, hotels and } \\
\text { shopping easier Most Arab tourists take large }\end{array}$ & $\begin{array}{l}\text { Improve and diversify products for } \\
\text { tourists, utilise electronic technology } \\
\text { for information and buying to enable }\end{array}$ \\
\hline
\end{tabular}




\begin{tabular}{|l|l|}
\hline $\begin{array}{l}\text { families to homes suitable for families or furnished } \\
\text { apartments means less hotel infrastructure required } \\
\text { (ESCWA 2007) }\end{array}$ & $\begin{array}{l}\text { this, offering excitement \& } \\
\text { entertainment (WTO, 2004) }\end{array}$ \\
\hline $\begin{array}{l}\text { Preservation of historic sites/areas and heritage } \\
\text { buildings maintain \& publicise cultural identity of } \\
\text { Jordan (Jordan Tourism Board 2013) }\end{array}$ & $\begin{array}{l}\text { More congestion and crowding at } \\
\text { attractions, increased price of } \\
\text { property, services and goods for } \\
\text { locals }\end{array}$ \\
\hline $\begin{array}{l}\text { Access improvement, marketing enhancement (ILO } \\
\text { 2010) }\end{array}$ & $\begin{array}{l}\text { Lack of small owner-operator } \\
\text { businesses who lease sites from } \\
\text { government }\end{array}$ \\
\hline $\begin{array}{l}\text { Trial of public-private partnerships to diversify and } \\
\text { improve packages in quality and quantity and } \\
\text { improve investment incentives to create a middle } \\
\text { class owner-operator as manager (ILO 2010; WTO, } \\
\text { 2004) }\end{array}$ & $\begin{array}{l}\text { Some public spaces might need to be } \\
\text { privatised to encourage family } \\
\text { tourism investment; lack of cultural } \\
\text { cross-fertilisation where homestays } \\
\text { provide cultural experiences for } \\
\text { overseas tourists }\end{array}$ \\
\hline
\end{tabular}

Figure 3B. JORDAN: External (Environmental) Opportunities and Threats

\subsection{Suggested strategic plan, vision, goals, strategies and objectives}

4.2.1 Vision: Sustainable increased global tourism into exciting Jordan

Goal 1: To exploit central location, proximity to tourism suppliers, internal political stability, unique ancient heritage of cultural and historical sites and educated cosmopolitan population sustainably to increase tourism numbers

Goal 2: To utilise economic stability and Central Bank, which has proper transparent banking procedures, for secure investment from overseas in tourism resources

Goal 3: To develop strategies which to utilise and encourage private/family ownership of tourism businesses and medium enterprises

Goal 4: To trial public-private partnerships to diversify and improve tourism packages in quality and quantity and improve government investment incentives

to create a middle class owner-operator as manager group

Goal 5: To make further specific educational provision for tourism business and management skills in secondary and tertiary; utilise multi-lingual refugees temporarily

4.2.2 Priorities for action: in four strategic directions

Exposure online to increase awareness of Jordanian advantages as an enjoyable and unique leisure, Middle East educational or overseas medical destination 
Provide multi-lingual easy to access online information and downloadable brochures for travel agents and operators

Ensure customer service excellence by suitable training at all levels of public contact

Develop or improve products and capacity in three areas above, by judicious investment in infrastructure to create new products and in answer to demand for services

Strategies to increase exposure, including multi-lingual online access:

- Objectives: (i) Collaboratively determine an agreed image such as an ancient unique heritage of cultural sites; easily illustrated products for computer advertising and collaborative means of controlling and reinforcing on-line images and travel brochures of operators

- (ii) Colourful online illustrations with brief descriptions identifying importance of unique destinations to demonstrate rich potential of experiences offered using languages other than local Arabic, Urdu and Farsi: English, German, French, Chinese, Japanese and, as well as other large groups identified by airport inflow in Amman and UAE.

- (iii) Ensure and upgrade awareness training of hotel and travel agent staff for accessing information systems about day trips, provide brochures for interesting short trips offering appropriate guides with language skills

- (iv) Attract annual international meetings and conventions to new Jordanian venues by broader advertising and planned culture-themed entertainment

- (v) Above methods will multiply visits if customer service, welcome feelings and soft skill development is emphasised by employees in contact with public, increasing personal recommendations

Strategies to improve customer service excellence:

- (i) Government awards (star system) advertised to recognise and credit excellence for categories of tours, restaurants, hotels, cultural meal/entertainment providers and homestay services, thereby guiding visitors and motivating improvement

- (ii) Develop and ensure suitable training for managers, guides and employees, perhaps by insisting on Jordanian nationals training as second in command, to learn tourism asset management from international managers, as part of investment agreements; use research results to demonstrate benefits accruing

- (iii) Introduce work experience and internship programs where students have the opportunity to work at least two weeks or more on the job to gain unpaid appropriate skills and experience at vocational or post-school level

- (iv) For tourism planning and hotels/restaurants in universities, add basic hospitality and tourism skills to local high school curriculum, provide vocational training in the school-to-job area for unemployed youth; possibly negotiate with multi-national hotel management to 
ensure safe labour conditions and remuneration for Jordanian nationals and limit number of cheaper guest workers.

- (v) Upper middle class women are already working, in many small and medium family enterprises, women not engaged in childrearing can possibly overcome present socio-religious habits to provide supervised labour under a male family member so that potentially half the work-age population (female) can be employed

- (vi) Exploit bi- or multi-lingual refugees as temporary contract guides to translate for specific groups

Strategies to improve products and capacity:

- Objectives: (i) Under the Ministry of Tourism (because consistent, legal coordinated leadership is crucial): stakeholders might include selected representatives from governorates, city authorities and local communities, Chambers of Commerce, ICCI(?), business and marketing, IT, history, university researchers, tourism, hotel and restaurant operators, which might be called say, a National Jordanian Tourism Reference Group (NJTRG), to examine analysed data, suggest new or different ways to satisfy demands of tourists and cope with future projected problems, including suggesting grant/loan recipients to build more Small and Medium Enterprises (SMEs), including decisions recommendating competitive advantages of different governorates.

- (ii) Careful design (advised by operators) of short and long trips exploiting unique or unusual experiences demanded by specific sectors of the market: by age, available money, “culture vultures”, youthful entertainment group, back packers, ecology interest, thrill seekers, religious pilgrims and so forth.

- (iii) Sensitive supplementary preparation for tours with brief recyclable tapes or apps (helped by IT specialists from NJTRG), available for background for employees and tourists, consideration of accommodation, appropriate transportation, water, food, rest places available and comfort stops catered

- (iv) Consideration for size and numbers in group matched with carrying capacity of attraction, networking among operators (possibly with Egyptian operators) and local community, clear waste disposal arrangements to avoid site pollution

- (v) Ensure buildings and homestay houses are comfortable for guests, stylish or appropriate to suitably match the regional picture

Strategies to provide information access:

- (i) Ensure universities are covering business and marketing-related concepts for tourism in theory and practice; include hospitality and tourism basics in high school curriculum because it occupies 22\% of the population (2012) thereby creating a basic labour-savvy population and broadening thinking about tourism advantages (ii) Use tertiary business resources for initial formative research on tourism in specific places and areas, designing 
questionnaires, collecting, collating, and analysing data to suggest results and improvements for NJTRG at least annually

- (iii) Ongoing customer satisfaction monitoring as exercises in business courses to provide distilled relevant data to the proposed reference group, (NJTRG) who monitor and consider key issues

- (iv) Explore ways of maximising benefits to local communities, which could be locally publicised in the media to encourage a more positive view of tourism and further encourage marketing

Strategies to encourage public-private partnerships:

- (i) To diversify and improve tourism packages by collaborative consensus with local communities utilising tourists' feedback, operators', guides' and local observation to ensure sustainability; encouragement to train teens and family members on the job with annual feedback for assistance, where selected families live near an attraction/area

- (ii) Provision of seed funds (grants or loans) to local family groups, or offer low repayment loans with ongoing advice and training on hospitality and tourism management, to establish new or improved businesses guided by research from NTRG or assisted by a local business/marketing department of a university

- (iii) Consider freeing up or leasing government-owned land near eco- or scenic areas so local industries could try a public-private partnership to develop more small and medium enterprises to employ local labour and improve infrastructure if required; use Chinese idea of keeping land freehold but allowing foreign business to lease and invest in tourism infrastructure/buildings, with government holding $51 \%$ of business shares to retain "sleeper" control

- (iv) Encouragement of homestay visit hosts where households provide a short unique experience of living life in a Jordanian household; at least one family member must speak the guest language; outline guide ideas could be provided by the projected NJTRG who derive these from collaborative suggestions from Governorates and those already in this field

- (v) Ensuring stakeholder independence and regular input while preserving historic heritage buildings, so local developments enhance income and living standards, provided infrastructure exists; traditional ways in themselves are a tourist draw

\subsection{Weaknesses of strategic plan}

From the Weaknesses and Threats sides of the SWOT tourism analysis, the following weaknesses are collated: Jordan is still in a politically unsettled region; direct flights from world capitals are limited at present, particularly from the wealthy East Asian tourism area; intra-regional Middle Eastern flights are irregular, with poor Arab cooperation in arranging reciprocal tourism in the Middle Eastern region; limited government funds are available for investment because of low GDP; the need exists to encourage overseas investment, particularly from Saudi-Arabia or the Near East; socio-culturally, little appreciation is 
displayed by certain sectors for the benefits of tourism, with sometimes poor reactions and attitudes.

\section{Areas for future study}

Information and research spaces require filling in to more closely analyse present Jordanian tourism, particularly case studies of satisfaction with presentation of or facilities near worldrenowned attractions. Sustainability of tourism, particularly in eco areas requires ongoing documentation, as well as monitoring in famous Petra, the Dead Sea, Karak, Jerash and Aqaba. A concerted effort to improve the gender balance in Tourism employment needs investigation if not execution, where unused female labour is probably willing to work under male family supervision if socio-religious barriers could be breached. This would support local ownership of businesses and give females more social responsibility and income, already observable in the upper middle classes. The hotel, catering and tourism sector needs further study to encourage opportunity for satisfying employee work, which is predicted to increase in growth over the next decade. For employment generally the Tourism Ministry needs to have meaningful dialogue with multinational (hotel) companies to establish minimum wages and conditions, career paths, including on-the-job training to facilitate more and better jobs for Jordanian nationals, both in managerial and other areas, informed by appropriate research, concentrating particularly on poverty reduction by local labour use. More languages taught in highschools might match tourism demand and reduce youth unemployment. All these areas can form solutions and examples for other Middle Eastern countries.

\section{Conclusion}

This research should generally be directed to improving, monitoring, sustaining and increasing the quality and quantity of tourism resources, especially environmental, encouraging more medical and educational tourism and assisting a better distribution of economic and social, particular gender benefits of tourism, within the recipient communities from the present $5.5 \%$ of Jordanian GDP contributed.

\section{References}

Alrabwa, Al Sayed, ICCI. (2013). Economic Development in Jordan: Story of Success and Achievement. Periodical Islamic Chamber of Commerce and Industry Magazine. http://web.archive.org/web/20121028220138/http://chambermag.com/en/details.

Alrabwa, Al Sayed, ICCI. (2013). Investment in Jordan: A way towards Success. http://chambermag.com/en/details. (Accessed Oct 8 2013)

AMEinfo.com. (2010). The ultimate Middle East business resource (weekly e-newsletter) Finance \& Economy section.

APN Shareholder Review. (2007). (Accessed Oct $10 \quad$ 2013) media.corporate-ir.net/media_files/irol/14/144006/.../radCTIAC.pdf

BBC News. (2007-01-24). Doors closing on fleeing Iraqis. Leyne, Jon. 
Chamber

of

Commerce

\&

Industry,

Jordan

http://web.archive.org/web/20121028220138/http://chambermag.com/en/details.asp?t=05\&ye armonthid=33\&idno=25 Archived from the original on 2012-10-28. (Retrieved Oct 8 2013).

CIA World Fact Book. (2013). http://cia-world-fact-book.findthedata.org.Accessed Oct 2.

CIA The World Factbook - Middle East: Jordan. (2013). (Accessed Oct 7). (https://www.cia.gov/library/publications/the-world-factbook/geos/jo.html

Downey, J. (2007) .CIMA Strategic Analysis Tools. Topic Gateway series \#34) CIMA London.

http://www.cimaglobal.com/Documents/ImportedDocuments/cid_tg_strategic_analysis_tools _nov07.pdf.pdf (Accessed Oct 15, 2013)

Eco and Nature: Aqaba, Wadi Rum Protected Area. (2013). http://international.visitjordan.com/Whattodo/EcoNature.aspx

ESCWA. (2007). The Annual Review of Developments in Globalization and Regional Integration in the Arab Countries, issued by Economic and Social Commission for Western Asia. United Nations: New York.

Gee, Chunk Y. (1997). International Tourism: A Global Prospective. World Tourism Organizationhttp://www.cimaglobal.com/Documents/ImportedDocuments/cid_tg_strategic_a nalysis_tools_nov07.pdf.pdf

Global Unions. (2010). ITUC, TUAC, Global Unions: Global Unions statement to the G20 Employment and Labour Ministers’ Meeting, Beating the Job Crisis, Apr., p. 7

IVC. (2006). The Economic Impact of Air Service Liberalization, Inter Vistas- Consulting, Inc.: (2013) http//: www.intervistas.us.

ILO. (2010). Developments and challenges in the hospitality and tourism sector. Issues Paper for discussion at the Global Dialogue Forum for the Hotels, Catering, Tourism Sector, ILO, Geneva, GDFHTS/2010 23-24 November $2010 \quad(, \quad 2013)$ www.ilo.org/wcmsp5/groups/public/@ed_norm/.../wcms_166938.pdf

Islamic Chamber of Commerce and Industry (ICCI). (2008). Databank presentation: Hasan, Syed Azar Ibne (n.d.) (2013) http://www.sesric.org/imgs/news/Image/Presentation-5.pdf

Jewish Virtual Library: CIA American Israeli Cooperative Enterprise. (2013). http://www.jewishvirtuallibrary.org/jsource/arabs/jordan.html

Jordanembassyus.org. (2012). Kingdom's medical tourism sector cracks global top five. 20 February 2011. (Retrieved July 26)

Jordan Famous Landmarks, Tourist Attractions and best Places to Visit. http://famouswonders.com/middle-east/jordan/ (Accessed Oct 7 2013)

Jordan Map \& Sites: At-last Tours: Jordan's tourist attractions map. www.atlastours.net/jordan/sites.html （Accessed Oct 7 2013) 
Jordan Tailor-made Holidays | On The Go Tours. www.onthegotours.com > Jordan (Accessed Oct 7 2013)

Jordan

Tourism

Board:

Ammam.

http://international.visitjordan.com/Wheretogo/Amman.aspx (Accessed Oct 7 2013)

Medical Tourism Jordan - Jordan Health Travel. Jordan Medical Tourism". http://www.medicaltourismco.com/jordan-hospitals/medical-tourism-jordan.php

Manketelow, J. MindTools, 2006. (Accessed Oct 12, 2013) https://www.mindtools.com/store/pages.php?pageid=9

Mustafa, Mairna Hussein. (2010). International tourism; number of arrivals in Middle East and North Africa. International Journal of Business and Social Science, 1(1) 37-48

Paajanen, George. (1992). Employment Inventory Reports, Technology Based Solutions/Personnel Decisions, Inc. (1) 1992. In Sangeetha, P, Priya, T.S., International Journal of Management Research and Review. 2(11) 1895-1901.

Pearce, D.G. (2002). Tourism and peripherality: Perspectives from Asia and the South Pacific.

Tourism and Hospitality Research, 3(4), 295-309.

books.google.com.au/books?isbn=1845934482

Sharp, Jeremy M. (2012-10-03). Jordan: Background and US Relations. US Congressional Research Service. pp. 7-8.

UN Human Development Report. (2011). (Oct 8, 2012) hdr.undp.org/en/reports/global/hdr2011/download/

UN Development Program. (2013). Regional and National Trends in the Human Development Index 1980-2011. United Nations Development Programme.

UNWRA. (2013). The UN and Palestinian refugees - Unrwa 2008. (2013). www.unrwa.org/userfiles/2010011791015.pdf

Upper-middle-income economies (\$4,086 to \$12,615). (Oct 5, 2012). http://data.worldbank.org/about/country-classifications/country-and-lending-groups

Jordan Tourism Board - Eco and Nature. (Oct. 9, 2013) http://www.visitjordan.com/default.aspx.

Jordan Holidays and Adventures Tours/ Wild Frontiers. (0ct 7, 2013). http://www.wildfrontierstravel.com/gb/world-regions/middle-east/jordan

Ft. com.cms. (2013). Harsh blow to Jordan's economy. http://www.ft.com/cms/s/7c904b80-a1a8-11e0-b9f9-00144feabdc0

Mowforth, M. \& Munt, I. (2003). Tourism and Sustainability, 2nd edition, London: Routledge. Pizam, A. 1978. Tourist Impacts: The Social Costs to the Destination Community as Perceived by its Residents. Journal of Travel Research, 16(4) 8-12. 


\section{Macrothink}

Journal of Management Research

ISSN 1941-899X 2014, Vol. 6, No. 1

Mustafa, M.H. (2010). International tourism: Number of arrivals in Middle East and Arab World. International Journal of Business and Social Science, 1(1), 37-4

RT News. (2013). Westernized media in Jordan breaking old taboos - RT".

UNHCR Syrian Regional Refugee Response Jordan. (Accessed 8 Oct 2013) http://data.unhcr.org/syrianrefugees/country. 536405.

Wiki. Jordan (Retrieved Oct 8 2013)http://en.wikipedia.org/wiki/Jordan

Winer, L. (2006). (Accessed $\quad$ Oct 2013). http://www.flickr.com/photos/51072101@N00/91829174/

Winnett, R.A. (1992). Behavioral Systems Framework for Media- Based Behavior Change Strategies. In M.J. Manfredo (Ed.), Influencing human behavior: Theory and applications in recreation, tourism, and natural resources management (pp. 103- 126). USA: Sagamore.

World Tourism Orgn. (2013). Compendium of Tourism Statistics Data 2007-2011, http://statistics.unwto.org/en/content/compendium-tourism-statistics

World Tourism Organisation. (2013). Yearbook of Tourism Statistics, World Development Indicators. http://data.worldbank.org/indicator/ST.INT.RCPT.CD

WTO. (2004). Tourism 2020 Vision: The Challenges and Opportunities for Middle East Destinations, a presentation by A. Abdel-Ghaffar (a regional representative of WTO for the Middle East) in a seminar on E- Tourism: The Route to Competitive Success, Damascus, Syria.

World Travel and Tourism Council (WTTC): Jordan. (2013). http://www.wttc.org/site_media/uploads/downloads/jordan2013_1.pdf

WTTC Economic Impact 2013:11. www.wttc.org/research/economic-impact-research/ 